


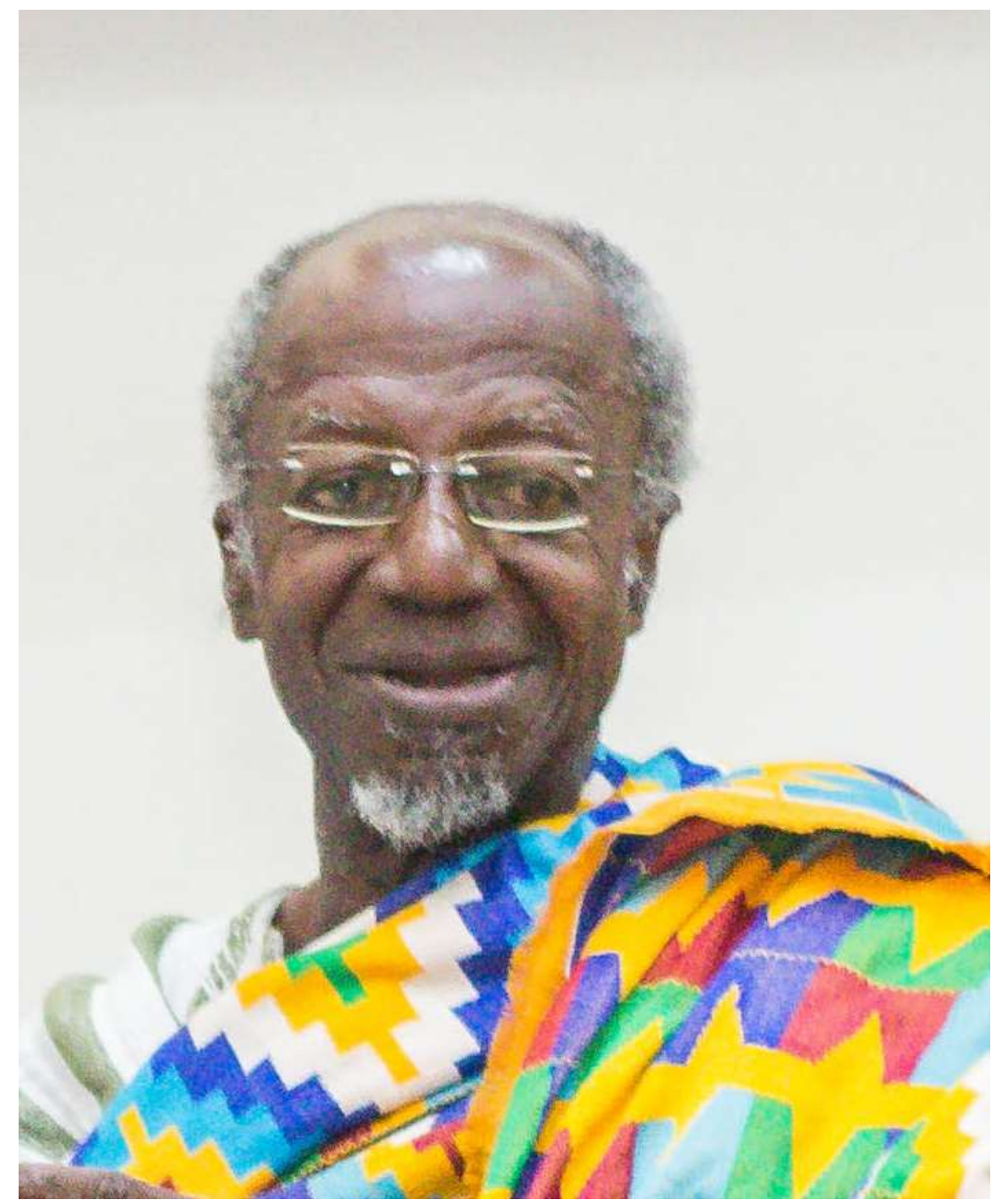

PROFESSOR ATTA GYAMFI BRITWUM 


\section{THE BILINGUAL LITERARY JOURNAL OF THE FACULTY OF ARTS UNIVERSITY OF CAPE COAST}

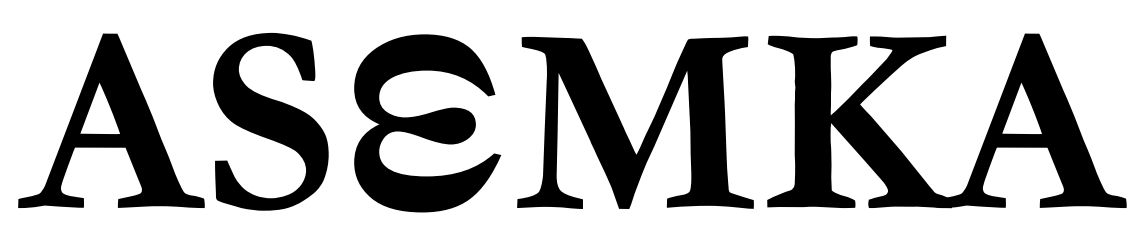

NUMBER 10

SEPTEMBER 2020

\section{EDITORIAL COMMITTEE}

Editor-in-Chief: Prof. Samuel Awuah-Nyamekye (Ph.D.)

Editor: $\quad$ Prof. Mawuloe Koffi Kodah (Ph.D.)

Associate Editors: Dr. Samuel Kwesi Nkansah

Dr. Mrs. Theresa Addai Munumkum

Dr. Isaac Mwinlaaru

Business Editor: Rev. Sr. Dr. Matilda Alice Nsiah

\section{EDITORIAL STAFF}

Mr. Stephen Owusu-Amoh

Mr. Isaac Kweku Grantson

\section{EDITORIAL ADVISORS}

Prof. Kwadwo Opoku-Agyemang, University of Cape Coast.

Prof. Joseph B. A. Afful, University of Cape Coast.

Prof. Raymond N. Osei, University of Cape Coast.

Prof. Richard V. Cudjoe, University of Cape Coast.

Prof. Victor K Yankah, University of Cape Coast.

Dr. Mousa Traore, University of Cape Coast. 


\section{ACKNOWLEDGEMENTS}

We acknowledge the contribution of the underlisted members of the Department of French who did preliminary editorial work on the papers:

Dr. Anthony Y.M. De-Souza (Chairman)

Prof. Raymond N. Osei

Prof. Mawuloe K. Kodah

Dr. Sylvester P. Krakue

Mr. Ofosu Addo-Danquah

Mr. Micheal Donkoh (Secretary)

\section{SUBSCRIPTION}

Assmka is published twice in the Academic year by the Faculty of Arts, University of Cape Coast. The annual out-of-Ghana subscription rate, including air-postage, is US\$29 for individuals, and US\$ 59 for institutions and libraries. Single issue rate for individuals is US\$18. Claims for copies not received must be made within three (3) months following an issue's publication. Correspondence should be addressed to:

The Editor, Assmka

Department of French

Faculty of Arts

College of Humanities and Legal Studies

University of Cape Coast

Cape Coast

Ghana, West Africa

Email: asemkajournal@ucc.edu.gh

\section{ADVERTISING}

Advertising rate, size specifications and related information are available upon request. Please, contact the General Editor for more information.

\section{SUBMISSIONS}

Assmka is an internationally-refereed journal of the Humanities. It publishes scholarly and imaginative articles in Literature, Language, and Culture generally, including, Orature, Film, Theatre, Music and Art. Essays, Interviews, Book Reviews, Poetry, Short Prose Fiction and Drama are welcome. Submitted manuscripts, in English and French, must be prepared in accordance with the most recent of APA or MLA style manual, where applicable. The author's identity and address may appear only on the cover- 
page and nowhere else within the submitted manuscript. All manuscripts should be submitted electronically through:

asemkajournal@ucc.edu.gh

Manuscript will be duly acknowledged within two (2) months of receiving them. Individuals whose works are accepted for publication may provide Assmka with a brief bio-data. The Editors cannot be held liable for lost or damaged manuscripts. Material published by Assmka does not necessarily represent the views of the Journal's Editors, Staff, Financial Supporters or the University of Cape Coast and its affiliates. These parties disavow any legal responsibility related to all submitted material.

\section{BACK ISSUES}

Back issues of Ascmka that are in stock may be ordered from the Editor at US\$20 per copy.

\section{GRANT SUPPORT}

Assmka is funded through grants from the Office of the Dean, Faculty of Arts; the Publications' Board; and the Office of the Vice-Chancellor, University of Cape Coast, Cape Coast, Ghana.

No part of this Journal may be reproduced, stored in a retrieval system, or transmitted in any manner whatsoever without express permission from the Editors, except in the case of brief quotations embodied in critical Articles and Reviews.

Copyright (C2020 by The Editors and The Faculty of Arts, University of Cape Coast. The cover and page design elements were inspired by the Adinkra symbols of Ghana. 


\section{DEDICATION \\ PROFESSOR ATTA GYAMFI BRITWUM}

Professor Britwum is a man of many parts. He is as much at home with Marxist Economic Theory and Feminist Sociological Thoughts, as he is with French and Francophone Literatures. He is a great teacher and Administrator of international acclaim. The Editors dedicate this special issue of Assmka to his honour. 


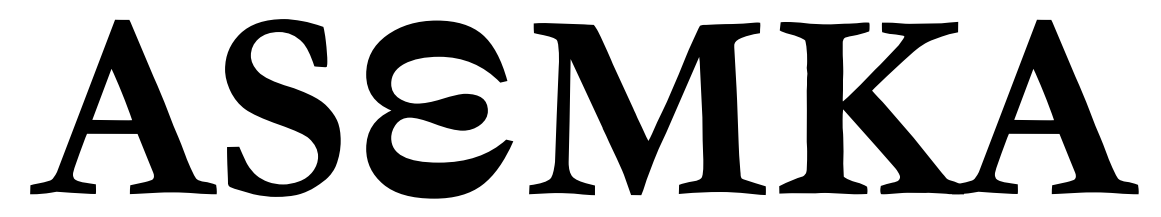

NUMBER 10

SEPTEMBER 2020 


\section{CONTENTS}

$\begin{array}{llll}\text { Editorial Committee } & \sim & \sim & \sim i i \\ \text { Editorial Staff } & \sim & \sim & \sim i i \\ \text { Editorial Advisors } & \sim & \sim & \sim i i \\ \text { Acknowledgements } & \sim & \sim & \sim i i i \\ \text { Subscription } & \sim & \sim & \sim i i i \\ \text { Advertising } & \sim & \sim & \sim i i i \\ \text { Submissions } & \sim & \sim & \sim i i i \\ \text { Back Issues } & \sim & \sim & \sim i v \\ \text { Grant Support } & \sim & \sim & \sim i v \\ \text { Dedication } \sim & \sim & \sim & \sim \\ \text { Foreword } \sim & \sim & \sim & \sim x \\ \text { Assmka: Editorial } & \sim & \sim & x i-x v i i\end{array}$

Articles

First Section - French

Britwum, A. G.

Insuffisances Théoriques Des Damnés De La Terre De

Frantz Fanon

$\sim$

$\sim 2-15$

Kodah, M. K.

Disculpation de Dieu dans le malheur des hommes:

Une lecture critique de Gouverneurs de la rosée de

Jacques Roumain $\sim \sim \sim 16-31$

Addo-Danquah, $O$.

Le récit de pensées: Une analyse comparative de Vol de nuit d'Antoine de Saint-Exupéry et La Condition humaine d'André Malraux

Kodah, M. K. \& Togoh, A. A. X.

Réactions des femmes face au conflit de genre dans C'est le soleil qui m'a brûlée et Tu t'appelleras Tanga de Calixthe Beyala

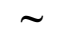

$\sim$

$\sim \quad 45-59$ 
Kudi, M. D.

La Littérature francophone face aux médias de télécommunication : Une nouvelle dynamique de la création romanesque, le cas de L'Énigme de retour et Tout bouge autour de moi de Dany Laferrière $\sim \quad$ 60-72

Gli, $M$.

Les faces du bonheur dans Vol de nuit d'Antoine de Saint-Exupéry $\sim \sim 73-85$

Krakue, S. P.

Christ haïtien : Gouverneurs de la rosée et La Bible $\sim 86-93$

Afari, E. S. K. \& Yegblemenawo, C. A. A.

Apports de la télésérie à l'amélioration de la compétence d'expression orale du FLE à l'école normale $\sim 94-116$

Bationo, J.-Cl.

Didactique de la littérature et littérature didactique:

l'exemple de la littérature africaine francophone en classe de langues étrangères au Burkina Faso

Second Section - English

Krakue, S. P.

Quod erat demonstrandum: A comparative study of narrative technique in Ama Ata Aidoo's Changes and Albert Camus'

Les justes (The Just Ones) 〜 $\sim$ $133-141$

Adjandeh, E. A.

Analysis of Wole Soyinka's Trials of Brother Jero in Relation to Ghanaian Religious Discourse

Sam, C. A.

Decolonizing the Postcolony: Of Men, Spatial Politics and the New Nation in WA Thiongo's Wizard of the Crow.

Kambou, M. K. \& Traore, S. A.

Manipulation and the popular uprising in Burkina Faso in 2014. 
De-Soura, A. Y.M.

Test-taking Strategies of University of Cape Coast Students of

French as a Foreign Language: a Case Study $\sim 191-216$

Kambou, M. K. \& Soma, L.

Local Culture and EFL Vocabulary Learning $\sim \quad 217-238$

Kabore, A. \& Nazortin, C.

Critical Analysis of the Place and Importance of Literature in the Teaching / Learning of English and in School Leaving Certificate Examination in Burkina Faso from 1985 to 2018

Malgoubri, I., Sawadogo, M. \& Kambou, M. K.

Digital Audio-visuals Aids and Listening in English as a

Foreign Language Classrooms

Osei, R. N. \& Inusah, $H$.

A Critique of the Images of Heaven in the Scriptures of the

Abrahamic Religions: An Existentialist Perspective $\sim$ 270- 282

Negedu, A. K.

Lexical Gaps and Ideological Shift in the Translation of

Chinua Achebe's Things Fall Apart as "Le Monde

S'effondre" in French $\sim \sim 283-297$

Talburt, $T$.

Political Transformation and Development in Africa:

Lessons from Achebe's Things Fall Apart

$\sim 298-313$ 


\section{FORWORD}

All the papers in this Volume were presented at a three-day Conference in honour of Professor Atta Gyamfi Britwum who turns eighty years in March 2021. Most of those years he spent at University of Cape Coast, having cut his teeth as a young lecturer in French language and Literature-in-French in 1974. After many years of an illustrious career in teaching, publication and extension, he bowed out at age seventy, but he didn't get the well-deserved rest he was entitled to; he continues to support his Department and the University as a whole. Today, Professor Britwum's name is associated with high standards of professionalism which earned him the nickname 'L'oracle'. Indeed, it is impossible to find another name universally acknowledged as embodying the excellence in French education offered at the Department of French, University of Cape Coast.

The decision to honour Professor Britwum couldn't have been taken at a more appropriate time. It was planned to coincide with the fiftieth anniversary of the publication of the Beautyful ones are not yet Born, Ayi Kwei Armah's first novel. Britwum never grew tired of reading, teaching and examining it. Such was his respect for Armah's craft. So, the three-day Conference was as much a celebration of Armah's contribution to the shaping of the African novel as it was a tribute to Professor Britwum's work as a teacher of literature of immense influence.

One only has to look at the titles of the papers published in this Volume to get an idea of how deep his influence runs at UCC and beyond. Most of the contributors once upon a time sat at the master's feet, but are now scholars in their own right keeping the flame of French scholarship burning bright (George Cooper: "Polished in a high degree, as each froggie ought to be/Now they sit on other logs, teaching other little frogs.") A good number of the papers are on Literature, nonetheless not limited to Armah's works. No Surprise there. Nevertheless, there are Language papers there too. No surprise here either, for the man to whose honour the Volume is dedicated is equally at home in both Language and Literature

\section{Lawrence $K$. Owusu-Ansah,}

Department of English, UCC.

A Disciple 


\section{$A S E M K A:$ EDITORIAL}

This Special Edition of $A S E M K A$, a bilingual literary journal of the University of Cape Coast, is published in honour of Prof. Atta Gyamfi Britwum, a revered Associate Professor of Francophone African Literature and Civilisation in the Department of French, U.C.C. It contains twenty (20) papers centred on diverse areas of teaching and research in the Humanities and on the theme of the Conference - Literature and the Humanities in the 21 Century: Interdisciplinary Perspectives - held in his honour by the Department of French, University of Cape Coast, Ghana, $13^{\text {th }}-15^{\text {th }}$ Mars, 2019. To reflect Prof. Britwum's area of research interest, the essays are arranged in two sections according to his dominant medium of instruction (French language) and speciality (Literature and Civilisation), followed by those in English language. The first section consists of a set of nine (9) essays in French spanning between themes in Literature and Language. The second section is made up of a set of eleven (11) essays in English which examine issues in literary studies, Language and Didactics, ICT and French Education, Philosophy, and Translation, among others. This special arrangement is however representative of the bilingual nature of the Journal.

\section{First Section}

Britwum, A. G.'s paper titled, “Insuffisances Théoriques Des Damnés De La Terre De Frantz Fanon", presents the Fanonian perspective as a complement to the African nationalism that informed anticolonial struggles. The study posits that African nationalism, populist in nature, for failing to target the capitalist economic base, which defines colonialism, ended up strengthening it. It concludes that Fanon's anticolonialist perspective, despite its overt radicalism, is not designed to allow a "bottom-to-top change" in colonial / capitalist society.

Kodah, M. K.'s paper titled, "Disculpation de Dieu dans le malheur des hommes: Une lecture critique de Gouverneurs de la rosée de Jacques Roumain", puts into question the responsibility of God in the suffering of men on earth and the capacity of man to make and unmake himself. The study aims at absolving God of the guilt of the miseries of men, and also questioning the atheistic or anti-religion denunciation of this narrative 
text since its publication. The study is accomplished through a critical reading and a thoughtful analysis of Jacques Roumain's Gouverneurs de la rosée within the analytical structure of literary studies and sociocriticism.

Addo-Danquah, O.'s paper, "Le récit de pensées : Une analyse comparative de Vol de nuit d'Antoine de Saint-Exupéry et La Condition humaine d'André Malraux", drawing inspirations from theorists such as Léon Edel (1961) and later Dorrit Cohn (1981), examines what Antoine de Saint-Exupéry's Vol de nuit by and André Malraux's La Condition bumaine respectively can offer on the side of representations of the interior life. The study is posited within the framework of narratological theories.

Kodah, M. K. \& Togoh Tchimavor, A. A. in "Réactions des femmes face au conflit de genre dans C'est le soleil qui m'a brûlée et Tu t'appelleras Tanga de Calixthe Beyala" examine the reactions of women to gender conflict in Calixthe Beyala's C'est le soleil qui m'a brulée and Tu t'appelleras Tanga. The study critically reflects on the various ways women in Beyala's C'est le soleil qui m'a brulée and Tu t'appelleras Tanga react to oppression and exploitation resulting from patriarchal domination. It therefore examines the sources and nature of this conflict, and how women react to it in the two novels. The study points to the fact that, much as conflict emanating from patriarchal oppression and male's domination in human societies is inimical to the rights of women, the methods used by the latter to free themselves from this state of being remain questionable, in that, these methods defy rational thinking and are also a kind of reversal oppression and domination which are equally unacceptable.

Kudi, M. D.’s paper, “La Littérature francophone face aux médias de télécommunication: Une nouvelle dynamique de la création romanesque, le cas de L'Énigme de retour et Tout bouge autour de moi de Dany Laferrière", seeks to examine how pertinent painting, photography, television, telephone etc. are to the production of the contemporary Francophone novel. The study focuses on L'Énigme de retour (2009) and Tout bouge autour de moi (2011). The analysis is based on the perspective of literary intermediality propounded by Jürgen E. Muller which is characterised by an interaction between telecommunication media and literary text. The study establishes through these selected novels that these media forms are not simply another form of expression in the novel but rather a lens through which the story is narrated. 
Gli, M.'s paper titled, "Les faces du bonheur dans Vol de nuit d'Antoine de Saint-Exupéry", analyses the faces of happiness in Antoine de Saint-Exupéry's Vol de Nuit. The study is conducted through thematic approach. This approach is complemented by Maslow's theory of human needs. The collection of data or the collection of information is purely documentary. The study therefore seeks to establish a link between individual happiness and collective happiness in Saint-Exupéry's selected narrative text.

Krakue, S. P.'s paper, “Christ haïtien : Gouverneurs de la rosée et La Bible", attempts to question Jacques Roumain's Gouverneurs de la rosée in order to elucidate the novelist's use of the biblical text in his creative activity. The study demonstrates that Jacques Roumain's narrative text turns out to borrow biblical ideas not only to develop his plot but also to design his main character.

Afari, E. S. K. \& Yegblemenawo, C. A. A. in “Apports de la télésérie à l'amélioration de la compétence d'expression orale du FLE à l'école normale." examine the impact examine the impact of the use of serial movies as teaching aid on oral expression of French language learners in Colleges of Education in Ghana with the aid of smartphones. The study discovers that the use of serial movies in teaching French boosts learners' performance in oral communication. It therefore recommends that serial movies could be used in teaching French language lessons in order to enhance the oral communication competencies among learners.

Bationo, J.-Cl.'s paper titled, "Didactique de la littérature et littérature didactique : l'exemple de la littérature africaine francophone en classe de langues étrangères au Burkina Faso", shows not only how to teach literature in language class but also how to use didactic literature to develop social skills among learners to reduce vandalism, school violence, negative stereotypes, misunderstandings of intercultural nature while cultivating social peace and living together in a context of internationalization, globalization and digital revolution. The paper focuses on francophone African Literature and posits that methodological approach used for the didactic transpositions of literary content is based on the new orientation and the redefinition of the objectives of language teaching and on the didactic models of the aesthetic reception of didactics of literature which requires putting the learner in intensive interaction with the text and motivating $\mathrm{him} /$ her to express himself/herself on his/her reading experiences. 


\section{SECOND SECTION - ENGLISH}

Krakue, S. P.'s paper titled, “Quod erat demonstrandum: A comparative study of narrative technique in Ama Ata Aidoo's Changes and Albert Camus' Les justes (The Just Ones)", demonstrates through textual analysis, how in Ama Ata Aidoo's Changes and Albert Camus Les justes, the authors resort to a specific form of irony to bring the discussion of issues raised to a conclusion. The technique consists in demonstrating clearly a huge discrepancy between a "fine" idea and its practical usefulness. Both authors successfully use narrative technique. Albert Camus demonstrates the hollowness of the idea of fighting for justice through revolutionary violence and Ama Ata Aidoo similarly demonstrates the fatuousness of the theory of women-emancipation-through-polygamy.

Adjandeh, E. A. analyses selected reports in Ghanaian media in relation to the clergy and identifies how Wole Soyinka's theme is reflected in these media in her paper titled, "Analysis of Wole Soyinka's Trials of Brother Jero in Relation to Ghanaian Religious Discourse". The study seeks to examine the extent to which themes in Soyinka's Trials of brother Jero play out in religious discourses in Ghana. The global nature of the issues problematized by Wole Soyinka also comes out through this study as the work set in Nigeria is analyzed in relation to the selected articles set in Ghana. The paper relies on a content analysis of Trials of Brother Jero and similar themes presented in the selected articles, and makes a few recommendations on how these religious issues could be partially, if not wholly, resolved in Ghana.

Sam, C. A.'s paper, "Decolonizing the Postcolony: Of Men, Spatial Politics and the New Nation in WA Thiongo's Wizard of the Crow", examines how Ngugi Wa Thiongo's Wizard of the Crow blatantly explores Africa's complicity in a seemingly cyclic colonization in the $21^{\text {st }}$ century and its attendant consequences for the total liberation of Postcolonial Africa. The study examines the correlation between masculine representations, spatial reorganization and futurity as alternative ways in thinking about Africa's future through Bakhtin's theory of the carnival and other such concepts as polyphony and the grotesque. The result of the analysis is that the correlation between forms of communities and forms of masculinities is an indication of a vision of hope for Postcolonial Africa. 
Kambou, M. K. \& Traore, S. A. in "Manipulation and the popular uprising in Burkina Faso in 2014", analyse the different discourses in the build-up to the popular uprising in Burkina Faso on the $30^{\text {th }}$ and $31^{\text {st }}$ October 2014. It attempts to clarify how political and civil society leaders use language and other non-linguistic elements to influence the ordinary citizens' minds and, indirectly, their actions. The analysis is premised on Van Dijk's (2006) Sociocognitive approach. The paper analyses the cognitive, the social and the discursive dimensions of manipulation in six political speeches (two speeches from Civil Society, two from the ruling party and two from the political opposition). The results suggest that the three groups manipulated their audiences, and finally, the ruling party lost following the resignation of the then Head of State, making way for a Transition government to take over the reins of governance.

De-Souza, A. Y. M.'s paper “'Test-taking Strategies of University of Cape Coast Students of French as a Foreign Language: a Case Study.” seeks to provide a description of test-taking strategies that may inform teaching and learning of French for better output in tests against the background that Ghanaian students of French as a foreign language deploy strategies that are not adequate enough in answering test items in French. The study examines data gathered right after a French test by level 200 students, using recollective verbalization protocols.

Kambou, M. K. \& Soma, L. examine in their paper titled, "Local Culture and EFL Vocabulary Learning”, the influence of learners' culture on foreign language vocabulary. The paper seeks to demonstrate that there is a link between culture and lexico-semantic errors committed by learners of English as a foreign language among Dioula speaking students in Burkina Faso. A language test composed of two written activities was used as the data collection instrument. The results revealed that the Dioula speakers' English is influenced by their culture. These results have some pedagogical implications. They, therefore, suggest that we adapt the teaching of EFL vocabulary to learners' culture.

Kabore, A. \& Nazortin, C. in "Critical Analysis of the Place and Importance of Literature in the Teaching / Learning of English and in School Leaving Certificate Examination in Burkina Faso from 1985 to 2018", analyse the types of texts given at the "Baccalaureate A" written examination in the last thirty years. In this study, quantitative and qualitative 
data are collected. Baccalaureate written English papers are the main focus of our collection. Teachers and supervisors are interviewed. The study is grounded on "Reader-Response Theory" which stresses the interactions between the reader and the text. The results of the study show that the great majority of texts proposed for "Baccalaureate A" examination, in the last thirty years, are non-literary texts.

Malgoubri, I., Sawadogo, M. \& Kambou, M. K.’s paper titled, “Digital Audio-visuals Aids and Listening in English as a Foreign Language Classrooms", is an experimental study which investigates the potential of digital audio-visuals to improve the listening skills of EFL learners in secondary schools in Burkina Faso. On the assumption that learners born around the year 2000 are digital natives, the researchers try integrating smartphone-friendly audio-visuals in their EFL classrooms in a four-week experiment involving one Experimental Group and one Control Group. The experiment aims at gauging the effectiveness of those aids operated via students' smartphones in improving learners' listening and speaking skills. Independent T-tests were used to compare the groups and Sample Paired TTests to make comparisons within groups. The study suggests that, if appropriately used, smartphones are excellent devices for language teachers and learners in this digitizing world.

Osei, R. N. \& Inusah, H.'s paper, “A Critique of the Images of Heaven in the Scriptures of the Abrahamic Religions: An Existentialist Perspective." Critically examines the scriptural images of heaven as captured in the Abrahamic religions - Judaism, Christianity and Islam - from the existentialist perspective. The paper argues that the idea of life beyond this earthly existence for all human beings in a specially prepared location by God for eternal happiness for those who obey His commands on earth called Heaven, as propounded by the Abrahamic Religions, throws up a lot of problems, especially from the existentialist perspective. The study concludes that the scriptures' constructs of heaven appear self-contradictory and fail to strike a chord with the contemporary image of the ideal society when perused from the existentialist perspective and should, therefore, be discarded.

Negedu, A. K.'s paper "Lexical Gaps and Ideological Shift in the Translation of Chinua Achebe's Things Fall Apart as "Le Monde S'effondre" in French." examines the ideological divergence between the title of the original text and the title of the translation, following an observation 
that in translating Chinua Achebe's Things Fall Apart, Michel Ligny translates directly Igbo terminologies, realities and beliefs into the French language. The paper concludes that the ideology that the translated title projects to French-readers is totally different from the ideology that the original title projects to English-readers.

Talburt, T., in "Political Transformation and Development in Africa: Lessons from Achebe's Things Fall Apart", formulates critical perspectives on the significance of Achebe's novel for the socio-political and economic transformation and development of the African continent. The paper challenges one of the central assumptions in this story that Africa falls apart as soon as it comes in contact with Europe. It questions aspects of political conservatism exhibited in Okonkwo who is suspicious of fundamental changes to his society. The discussion is based on the jollof rice principle of political hybridisation of development which proposes the amalgamation of Westernised and non-Western ideas and systems, in order to achieve economic development, rather than totally rejecting Westernisation in its entirety. The study uses examples of Western-style democracy and State intervention in Africa to demonstrate the significance of embracing some aspects of Westernisation through political hybridisation. 




\title{
Analysis of Wole Soyinka's The Trials of Brother Jero in Relation to Ghanaian Religious Discourse.
}

\author{
Evelyn Aku Adjandeh \\ University of Cape Coast, Cape Coast, Ghana.
}

\begin{abstract}
One of the roles of Literature is its aesthetic value. Aside from that literary works serve as important tools that are used to comment on issues of society since most writers base their writings on their societal occurrences. While agreeing with the reflectionist theory of art that Literature reflects the society from which it emerges, this paper underscores that through writing, literary works have often sought to correct the ills of society. Wole Soyinka's The Trials of Brother Jero satirizes the work of the clergy. The paper analyzes selected reports in the Ghanaian media in relation to the clergy and identifies how Wole Soyinka's theme is reflected in these papers. The presence of Soyinka's theme in these reports is a reaffirmation that literary writers do not only present fiction but also express pertinent realities. This study seeks to examine the extent to which themes in Soyinka's Trials of Brother Jero play out in religious discourses in Ghana. The global nature of the issues problematized by Wole Soyinka also comes out through this study as the work set in Nigeria is analyzed in relation to the selected articles set in Ghana. The paper relies on a content analysis of The Trials of Brother Jero and similar themes presented in the selected articles and makes a few recommendations on how these religious issues could be partially, if not wholly, resolved in Ghana.
\end{abstract}

Keywords: content analysis; literary writers; newspapers; religious discourse; reflectionist theory; satire.

\section{Introduction}

Wole Soyinka is described as a legend in the literary world. His obsession with playing the role of a mouthpiece for his people and presenting 
a meaningful African culture and world view has made him playwright, poet, novelist, film producer and a critic.

Some of his earliest plays written during his time in London include, The Swamp Dwellers and The Lion and the Jewel, which were performed at Ibadan in 1958 and 1959 respectively and were published in 1963. He later wrote satirical comedies like The Jero Plays: The Trials of Brother Jero (1964). Some of his other plays are Camwood on the Leaves (1973), The Road (1965), and The Strong Breed (1969).

As a dramatist, Soyinka has been influenced by people like "the Irish writer J. M Synge, but he links up with the traditional popular African theatre with its combination of dance, music and action" (www.nobelprize.org). Just like Synge and most African writers deal with issues concerning their various societies, Wole Soyinka also uses the stage to dramatize some of the issues that affect Africa and Africans, be they social, economic and political (Tessa, 2014).

In The Trials of Brother Jero, Soyinka uses the stage to bring to the limelight some of the activities of Charismatic Churches and the way the "men of God" play on the ignorance of their members. These preachers prevent their followers from applying pragmatic methods to arrive at practical and dependable solutions to their problems. This paper analyzes how the themes of The Trials of Brother Jero reflect religious discourses in Ghana.

In the next section, the paper discusses the theoretical framework for the ensuing analysis. The penultimate section provides a discussion on the play and uses media (print and online) publications to examine how The Trials of Brother Jero reflects religious happenings in contemporary Ghana. Brief remarks are then provided by way of conclusion. Let's turn to the theoretical basis of the discussion.

\section{Theoretical Framework}

The paper uses the reflectionist view of art as a basis for the discussion. The reflection theory of literature states that there is a relation between literature and society (Watt 1964, Finnegan 1977). According to Watt:

All writing cannot but be a reflection of society since it contains many elements which are socially derived. Language, to begin with, is a social product and most writings, certainly, most literature, are related to some established tradition or model of expression (Watt 1964:396, 307).

This view of Watt is buttressed by Finnegan's comment that, "All literature in an indirect and subtle way must reflect the society in which it exists" (Finnegan 
1977:273). This theory of reflection, therefore, confirms the idea that literary works serve as a mirror through which a society can be viewed. This theory, therefore, confirms the relation between Soyinka's The Trials of Brother Jero and what pertains in current religious discourse across Africa. Gloudsblom (1979) expresses the reflectionist view of literature further by pointing out that:

This relation between art and literature is not simply a reflection in the sense of mirroring reality. Literary imagination should be seen as a continuation and an extension of the human experience. That continuation can be a 'reflection' of the social world, but it may also be a 'reflection' or expression of what people hope for, deny or fear (Cited in Nanbigne 2008:129).

Gloudsblom, therefore, makes the case that literary works can also be a projection of what will pertain in the future based on current happenings. Nketia observes same about songs, and says, in songs are laid plain the hopes, fears, joys and worries of the homo africanus (Nketia, 1963).

This is clearly shown in The Trials of Brother Jero in that a work written as far back as 1964, presents issues that are very similar to occurrences of today. Soyinka can therefore be described as a prophet or soothsayer predicting religious happening many years after his writing.

When Soyinka wrote his play, the text sought to reflect happenings in Nigerian society in the 1960s. Nigeria could thus be seen as the immediate society that the play reflects. The Trials of Brother Jero however has transhistorical value and seem to depict happenings in societies beyond Nigeria. The themes of the play seem to speak even to present situations in Ghana and other parts of Africa. Contemporary religious practices in Ghana lean themselves considerably to real life version of this satirical work. Thus, The Trials of Brother Jero reflect the immediate society within which it is set, and distant societies such as Ghana where the depicted religious practices are observable.

It is important to note that there are some scholars such as Aristotle (1985) who do not agree to the reflectionist role of literature. According to Aristotle (ibid), literary works are not factual but are works of fiction hence cannot be said to be a reflection of society. He also reiterates that literary works do not present what has happened but what may happen. Despite his opposition to the reflectionary aspect of literature, there are other scholars who concur that literature reflects society. Anjana and Bhambhra (2016:7) for instance write that, "It is impossible to find a work of literature that excludes the attitudes, morals and values of the society since no writer is separated from 
the forces and happenings that surround him". Vatsa (2016) also agrees to the reflective view of literature and goes ahead to point out that this reflection helps people to make a retrospection of their lives and make changes if necessary.

Vatsa's point, therefore, brings to the fore the satirical role of literature. As a result, scholars such as Priebe (1980), Mireku-Gyimah (2013) and Mohan (2018) have discussed The Trials of Brother Jero as a satire. Missing in this literature is the connection between this imaginative work and realistic events especially in the Ghanaian context. This paper therefore explores this play in relation to what pertains in current religious discourse by focusing on activities of Charismatic churches in the country.

\section{Discussion}

In making a connection between The Trials of Brother Jero and real events in Ghana, the discussion in this paper draws from print and online news sources. However, in an era where there is considerable fake news, it is necessary to hold news published online and in print with a pinch of salt. Some news from online news portals sometimes turn out to be untrue. The veracity of this reportage is usually laid bare through sourcing information from the particular person or organization about whom the news has been written. Sometimes it is only realized as fake news when there is counter publication from the affected individual or entity which seeks to correct the false story. The publication outlet may also be forced sometimes to retract the publication and offer apologies or even face legal suit.

While conscious of these issues, the publications used in this paper have yet to be openly contested by the affected religious practitioners. Additionally, the author has yet to read counter publications that suggest that the stories used for this analysis are untrue despite the necessary caveat that the casting of the news may not always present matters as they exactly were for the purposes of news. Alternatively put, author's search of print and online media for contrary stories or contestations about the selected reports did not show objection to these stories. Although interviewing the affected persons is great idea, the constraints of this exercise including challenges of access to these religious practitioners mean that such verification interviews could be a consideration for future research which may have more time to negotiate the difficulty. The discussion will now turn to the play and its connection to real events in Ghana.

To start with, the title of the book, The Trials of Brother Jero and what constitutes these trials is one factor that cannot miss an academic eye in analyzing the influence of religion on its adherents. Brother Jero informs the 
reader that his trials are as a result of a curse pronounced on him by his old master. Jero says that:

...My whole purpose in coming here is to show you one rather eventful day in my life, a day when I thought for a moment that the curse of my old Master was about to be fulfilled. Ingrate Monster! I curse you with the Curse of the Daughters of Discord. May they be your downfall. May the Daughters of Eve bring ruin down on year head! (Soyinka ${ }^{1}, 1964: 10$ and 11).

Owing to the fact that Jero regards his trials as a curse, he does not take time to reflect upon his life and see what he does wrong. He rather resorts to prayers with the belief that the Lord will protect and deliver him from the curse. "It shook me quite a bit but God protects his own" (p.10).

One of the things that constitute Jero's trials and which most often lead him into problems is lust. Instead of devising practical steps to deal with this weakness, he sees it as part of his trials and then prays for God to help him. His prayer goes as follows: "Every morning, every day I witness this divine transformation $\mathrm{O}$ lord...Tear the image from my heart. Tear this love for the daughters of Eve." (p. 20 and 21)

Brother Jero continues to look at the nakedness of women but still says that his problem is a trial and a temptation. Jero's problem of lust is what leads him to an encounter with an angry woman following a drummer boy. Unable to control himself after seeing the woman's exposed limbs, Jero runs after her. In the long run, Jero comes back with injuries: "Brother Jero has come in view. They all rush to help him back into the circle. He is a much altered man, his clothes torn and his face bleeding." (p. 30)

Brother Jero can prevent this "trial" if he decides not to follow the woman. However, he fails to solve this problem because he regards it as a curse and does nothing to overcome it but depends on prayers. Similar reports abound in the Ghanaian media about pastors having illicit sexual affairs. An example of this illicit sexual affair by a pastor was titled, Popular Ghanaian Pastor Allegedly Caught in Bed with a Married Woman. The pastor, Nana Appiah was caught having sex with a married woman (http://www.pulse.com.gh).

One can also look at the influence of religion on Chume, an assistant to Brother Jero. Chume is the husband of Amope. He is always with Jero because he has a troublesome wife who gives him problems at home. Instead of Brother Jero addressing the conflict between the couple, he tells Chume that he should bear the problem as his cross and then offers prayer for him. 
Brother Chume, this woman whom you so desire to beat is your cross- bear it well. She is your heaven- sent trial- lay not your hands on her. Pray Brother Chume, for strength in this hour of your trial. Pray for strength and fortitude. (p. 24).

In this case, because Chume considers the problem as a "heaven sent trial", he always relies on prayers to overcome the problem. Religion then becomes "the soul of the soulless condition" and "the heart of the heartless world" (Marx 1976 cited in McKinnon, 2005, p. 15) ${ }^{2}$ because it serves as hope and encouragement to Chume in his situation. This is the case in most homes, where problems remain unresolved because they are considered as trials. Instead of the family to find time and talk issues over, they go for long prayer sessions where they end up receiving revelations that compound the problem.

Contrary to Jero's initial instruction, he later orders Chume to beat his wife. Consequently, Chume hurriedly goes home to beat his wife. This decision, however, has nothing to do with God; it has everything to do with Jero's survival and public image. The decision was because Jero suddenly realises that the same woman he owes happens to be Chume's troublesome wife. Without any interrogation on the sudden change of mind from Jero, Chume gets convinced with Jero's explanation that, it is the will of God for him to beat his wife. Chume gets under the control of religion to the extent that he cannot bring out a suggestion, take a stand or question anything that seems strange to him.

In Chume's case, one can say that the time he spends with Brother Jero in view of getting solutions to his problem, has been a wasted one. These adherents of religion do not only rely on religion but they also become slaves to religion because they try to follow whatever instruction the "men of God" give them even if they realize these instructions are absurd. A report with the title, Bishop Obinim Stomps on Pregnant Woman's Belly during Exorcism, for example shows how the named Bishop in the name of religion mistreated pregnant women while the latter just heeded to the instructions of this religious practitioner. In another instance entitled Obinim Punishes a Woman to Carry a Bag of Cement Around for Lotto Numbers, he also asked a member of his church to carry a bag of cement for more than an hour in order to give her lotto numbers (https://www.ghanaweb.com). The desperation of the victims and their respect for the so called pastors make them accept every instruction or behavior of the pastors in the name of religious directive, no matter its effect and absurdity.

One of the ways through which these men of God influence their congregation and get their tricks materialized is to convince them that they are 
the chosen of God. For instance, in the very beginning of the play Jero tells the congregation that:

I am a prophet. A prophet by birth and by inclination...In fact there are eggs and there are eggs. Same thing with prophets. I was born a prophet. I think my parents found that I was born with rather thick and long hair. It was said to come down right to my eyes and down to my neck. For them, this was a certain sign that I was born a natural prophet (p. 1).

Jero makes this declaration at the very beginning of the play to set the pace for his activities. No wonder most of the members of the congregation accept every word of his with all seriousness. Closely related to this is that, these gullible followers are convinced that these so-called prophets hear from God directly and the followers must heed to their directives and instructions since that is the voice of God.

From The Trials of Brother Jero, it can be realized that there is a motivating factor propelling the followers and these gullible pastors to engage in the religious game. On the part of the prophets, the need for economic survival and for some, aggrandizement has led many of these prophets to resort to religion to achieve their aim. This is clearly demonstrated in the book thus, "I always get that feeling every morning that I am a shop keeper waiting for customers. The regular ones come at definite times" (p. 20). Later Jero's quest for survival is clearly revealed when he said:

One of my faithful adherents - unfortunately, he can only be present at weekends- firmly believes that he is going to be the first prime minister of the new Mid-North-East State when it is created. That was a risky prophecy of mine, but I badly needed more worshippers around that time (p. 25).

Brother Jero, therefore, regards his followers as "customers" which he "badly needed" to survive. This is not too different from what pertains today. Some pastors in Ghana market particular products to followers and levy fees on members for so-called spiritual directives ("akwankyere") as means for survival or creation of wealth. Through this strategy some pastors own companies and assets. It has been reported about Reverend Obofour, for example, that he owns about 14 to 15 companies. In a report captioned: How Rev. Obofour makes His money and List of Businesses Finally Revealed, the prophet (Rev. Obofour) 
revealed that the money he makes from the sale of witches' cream in a week can buy about 20 cars (https://www.ghpage.com).

The desperate desire of these prophets to realize their aims makes them to devise various strategies such as strange directives. For instance, Jero advises his assistant, Chume to beat his wife, Amope. This is because the prophet later realizes that Chume's wife is the one he owes. So in order to prevent the woman from chasing him for her money, the prophet asks the husband to beat her. In another instance, Jero secretly eavesdrops on people's prayers and later presents that to them as prophecies. Jero's trick is not too different from the case reported in Daily Graphic captioned: Fake Prophets Dupe Scores of $\mathrm{GH} \phi 298,000$, Two Vebicles. According to the report, the two self-styled pastors were arrested for allegedly defrauding more than 400 people by giving them fake prophecies. The suspects are said to target well-established traders and other personalities, mainly in the Greater Accra Region and other parts of the country. Part of the report reads that Baisie, one of the suspects convinced a trader to accommodate the other suspect, Braimah, in her house in order to offer prayer at all times. While in the house, Braimah gave more information on the trader and her family to his friend who later relayed this information back to the trader as divine revelations (https://www.graphic.com.gh).

Apart from the prophets, the members also follow these prophets and succumb to their tricks. This point is illustrated by the fact that almost all the members of Jero's congregation were there to solve one need or the other. Jero's assistant Chume, had a troublesome wife and also needed a promotion from a laborer to a chief clerk (p. 23). One other faithful adherent "believes he is going to be the first prime minister of the new Mid-North-East State when it is created (p. 25). In the case of another follower, "She wants children so she is such a sad case" (p. 25). Amu Djoleto presents a similar case in Money Galore, about a man called Ofori Nartey but nicknamed conception contractor. He is unemployed but used to be a Methodist Catechist. This man spends his entire life hunting for well to do women who have difficulty in having children. He is found in the home of prophetesses. He is good at faking serious prayers, at singing, at playing the tambourine and at receiving the gifts of the spirit. When he is in his spiritual frenzy, some of these predictions come true. Whether they happen by chance, intuition, experience or wisdom no one knows. But he manages to give a child or two to some women. He rolls in the women's wealth and then abandons them when he is satiated.

Chume's prayer during one of the prayer sessions summarizes the desperate needs of Jero's congregants.

Tell our wives not to give us trouble. And give us money to have a happy home. Give us money to satisfy our daily 
necessities. Make you no forget those of us who dey struggle daily. Those who be clerk today, make them chief clerk tomorrow. Those who are messenger today, make them senior service tomorrow...those who are petty trader today, make them big contractor tomorrow. Those who dey sweep street today give them their own office tomorrow. I say those who dey walka today, give them their own bicycle tomorrow, those who have bicycle today, they will ride their own car tomorrow (p. 29).

It is learnt that "the enthusiasm of the response becomes, at this point quite empowering" (p. 29). This suggests that the prayers were touching on the needs of the congregants hence they were responding actively. The Ghanaian print and online media are replete with various reports on how Ghanaian pastors are devising various ways to give financial hope to their members. The giving out of lotto numbers by pastors has become a rising phenomenon in churches. One of such is Bishop Obinim who believes that he has the power to know the secret things of life and one of such prowess is to give lotto numbers to his members (https://www.ghanaweb.com).

A Ghanaian Parliamentarian, Kennedy Agyapong, did not mince words while commenting on these religious activities. He especially decried those pastors who give out lotto numbers, asking when that became part of the work of God (https://yen.com.gh). The unfortunate part of these activities is that some of these gullible followers end up losing the money they have in a bid to get more money. One cannot gloss over the report captioned, Money Ritual Church Emerges in Ghana. The pastor by name, Sika BJfoJ whose church is located in the Western Region of Ghana, claims he can conjure money from heaven. According to the report, he actually commanded money from 'heaven' on Friday, his birthday and asked congregants to bring empty sacks to fetch the bank notes away (https://www.pulse.com.gh). In another report, a pastor deceived his congregation that he will help them to become rich. The pastor asked the members to bring some money which he will pray over but at the end the members got duped by the man of God (www.myjoyonline.com). These dubious activities resonate in Armah's (1970) Fragment as recast by Ameyibor (2002) that: "when the masses are in distress and turn to God for relief and salvation, the crooked men of God rather milk them dry" (p.1).

The lucrative nature of this business has led to situations where these so-called men of God struggle with each other over members and space to preach the gospel. In The Trials of Brother Jero, we are informed about how these pastors struggle over members. This information is expressed in the following words: "Mind you, the beach is hardly worth having these days. The 
worshippers have dwindled to a mere trickle and we really have to fight for every new convert" (p. 10). This struggle for new members has been observed to extend to struggle for preaching space in some Ghanaian contexts. Reports in Ghanaian media reveal cases of pastors struggling over space and people to preach to. A case in point is a story entitled, Two Pastors Fight in Trotro for Preaching Space. It was reported that there was a state of pandemonium in a commercial vehicle as two pastors fought each other over space to preach the gospel https://www.ghanaweb.com). One will wonder why two people expected to be preaching the same message fight each other for space. One could have easily supported the other. The question then is what is the motivating factor for preaching the message? Anyidoho's poem, Go Tell Jesus captures the same concerns. Part of the poem reads, "Go tell Jesus that his messengers have come but they have forgotten the message".

\section{Conclusion}

The 2018 Ghana demographic report reveals that $75 \%$ of Ghanaians are Christians. This suggests that a greater percentage of people will find themselves in one denomination or the other. Although not all religious leaders can be categorized as charlatans, the reports, some of which have been cited in this paper, suggest that there are a number of these false prophets in operation. It is therefore important that all should be vigilant and not fall prey to these charlatans. Another point of this paper is that the desperate needs of people have compelled them to accommodate some excesses from these prophets as pointed out by Soyinka and the newspapers. This, therefore, suggests that the more difficult economic situations become, the more people will resort to using religion to outwit the desperate and rely on them for economic survival. The desperation to achieve solutions to life's problems will also increase the number of people who will fall victim to these impostors. One way in which literary scholars can contribute to alleviating this phenomenon is not to reduce these literary texts to mere documents for academic assessment but as a tool for shaping society.

\section{Notes}

1. From here the name and year of the main text will not be repeated but only the page number.

2. McKinnon uses the phrase "the spirit of a spiritless situation" instead of "the soul of the soulless condition" which is the initial rendering of Marx (1976). 


\section{Reference}

Abbey, E. (2017). Fake prophets dupe Scores of GHф298,000, two vehicles. https://www.graphic.com.gh.

Ameyibor, F. (2002, October 13). The Charlattan Pastors. Ghana Web, pp. https://www.ghanaweb.com/GhanaHomePage/NewsArchive/TheCharlatan-Pastors-28236\#.

Anjana, B., \& Bhambhra, R. (2016). Is Literature the Mirror of Society? International Journal of English Language, Literature and Humanities, 6-10.

Anyidoho, K. (1985). Earthchild with Brain surgery: Poems. Accra: Woeli Publishers.

Aristotle. (1985). Poetics. New Delhi: Kalyani Publishers.

Armah, A. (1970). Fragment. London: Heinemann Publishers.

Aryee, N. (2019). I'll Never go to Church because Ghanaian Pastors are Fake and Deceitful. https://yen.com.gh.

Brown, L. (2019). How Rev. Obofour makes His Money and a List of Businessess Revealed. https://www.ghpage.com.

Djoleto, A. (1975). Money Galore. London: Heinemann.

Dokosi, M. (2014). Obinim Again: New Video Shows him Stomping on Pregnant Women.

https://www.ghanaweb.com/GhanaHomePage/NewsArchive.

Finnegan, R. (1977). Oral Poetry: Its Nature, Significance and Social Context. Bloomington and Indiapolis: Indiana University Press.

Kamasah, A. (2018). Popular Ghanaian Pastor Allegedly Canght in Bed with a Married Woman. https://www.pulse.com.gh/p.

Kamasah, A. (2018). Two Pastors fight in trotro for Preaching Space. https://www.pulse.com.gh.

Marx, K. (1976). Introduction to a contribution to the critique of Hegel's Philosopy of right. New York: Collected works v. 3.

Mckinnon, A. M. (2005). Reading 'Opium of the People': Expression, protest and dialectics of religion. Critical Sociology, 15-38.

Mireku-Gyimah, P. (2013). Soyinka as a Satirist: A Study of Trials of Brother Jero. International Journal of English and Literature, 269-282. 
Mohan, K. (2018). Satire and Irony as Farce in Wole Soyinka's The Trials of Brother Jero. Journal of English Language and Literature, 128-131.

Nketia, J. (1963). Drumming in Akan Communities of Ghana. Edinburgh: Thomas Nelson and Sons Limited.

Priebe, R. (1980). "Soyinka's Brother Jero: Prophet Politician and Trickster". In G. J., Critical Perspectives in Wole Soyinka (pp. 79-86). Washington DC: Three Continents Press.

Soyinka, W. (1973). Camwood on the Leaves. Eyre Methuen : North Rorkshire.

Soyinka, W. (1963). The Lion and the Jewvel. Oxford: Oxford University Press.

Soyinka, W. (1964). The Trials of Brother Jero. In W. Soyinka, The Jero Plays. Great Britain: Oxford University Press.

Soyinka, W. (1965). The Road. Oxford: Oxford University Press.

Soyinka, W. (1969). The Strong Breed. Oxford: Oxford University Press.

Soyinka, W. (1969). The Swamp Dwellers. Oxford: Oxford University Press.

Soyinka's Brother Jero: Prophet, Politician and Trickster. (1980). In J. Gibbs, Critical Perspectives on Wole Soyinka (pp. 79-86). Washington, DC: Three Continents Press.

Tessa, Z. (2014, September). J.M. Synge's The Shadow of the Glen and Wole Soyinka's A Dance of the Forests: A Postcolonial Study. Tizi Ouzou, Algeria: University of Tizi Ouzou. Retrieved from https://dl.ummto.dz/bitstream/handle/ummto/5072/Mas.\%20Ang. $\%$ 2013.pdf?sequence $=1$ \&isAllowed $=\mathrm{y}$

Vatsa, S. (2016). Literature is the Mirror of Society but Must Be Able To See The Mirrored. International Journal of English Language, Literature and Humanities, 115-124.

Watt, I. (1964). Literature and Society. In R. Wilson, The Arts in Society. Cliff: Prentice-Hall.

www.nobelprize.org. (n.d). Wole Soyinka-Biographical. The Nobel Prize, p. https://www.nobelprize.org/prizes/literature/1986/soyinka/biograph ical/.

Yeboah, F. (2018). Money Ritual Church Emerges in Ghana. https://www.pulse.com.gh. 
